\title{
Critical neuroscience meets medical humanities
}

\author{
Jan Slaby
}

\section{Correspondence to}

Professor Jan Slaby, Free University Berlin, Institute of Philosophy, Habelschwerdter Allee 30, Berlin D-14195, Germany;

jan.slaby@fu-berlin.de

Accepted 27 April 2015

\section{SLinked}

- http://dx.doi.org/10.1136/ medhum-2015-010702

CrossMark

To cite: Slaby J. Med Humanit 2015;41:16-22.

\section{ABSTRACT}

This programmatic theory paper sketches a conceptual framework that might inspire work in critical Medical Humanities. For this purpose, Kaushik Sunder Rajan's account of biocapital is revisited and discussed in relation to the perspective of a critical neuroscience. Critical neuroscience is an encompassing positioning towards the recent public prominence of the brain and brain-related practices, tools and discourses. The proposed analytical scheme has five focal nodes: capital, life, technoscience, (neoliberal) politics and subjectivity. A special emphasis will be placed on contemporary framings of subjectivity, as it is here where deepreaching entanglements of personhood with scientific practice and discourse, medical and informational technologies, and economic formations are most evident. Notably, the emerging subject position of the 'prospective health consumer' will be discussed as it figures prominently in the terrain between neuroscience and other medico-scientific disciplines.

\section{INTRODUCTION}

'Medical Humanities' has appeared on the academic scene as the friendly embrace of Humanities scholarship by the powerful sector of the biomedical sciences. As with other current interdisciplinary initiatives involving the Humanities, one is well advised to be a little wary of what goes on here. ${ }^{1}$ Could it be that the Humanities are absorbed, transformed, cancelled out in yet another managerial trick of the Neoliberal University? Is Humanities scholarship streamlined to accord with-give a human face to, promote, justify, ethicise and so on -the biomedical sciences and the ever-more influential health industries? Will we end up with an ideological masking of practices that will not be in any way impacted themselves by this kind of scholarship, let alone in progressive and transformative ways? In view of this danger, it is important to resort to the register of critique. Thus 'critical Medical Humanities' is an option in need of exploring, at least if we want to both assess the potentials of a new field at the intersection of medicine and the Humanities and at the same time stay true to high standards of scholarship and to the insights of relevant discursive and disciplinary traditions. ${ }^{2}$ For the moment, I leave aside the notorious debate on the alleged 'end of critique'. The case here is certainly not as straightforward as it is made to be by Latour ${ }^{3}$ and by other champions of a postcritique stance that gains currency in what is deceptively called a 'posthumanist' landscape. ${ }^{4}$ While not altogether dismissive about these trends, this paper instead starts from the assumption that a constant and thorough questioning of conceptual outlooks, epistemic orientations, disciplinary and institutional positions is a mandatory task in today's academic landscape.

In this contribution, I will outline an orienting framework for critique that provides crucial signposts for a programmatic in the prospective field of critical Medical Humanities. An exemplary terrain to be assessed initially is the landscape created by the successes of the neurosciences, especially its discursive, practical and technological surround, in the past circa 25 years. The central elements of the critical framework will then be drawn from a perspective developed by anthropologist Kaushik Sunder Rajan, ${ }^{5}$ initially geared to the field of genomics and developments in the biotechnology sector. In the final section, I will explain how this framework is adaptable to human neuroscience and how it might orient work in the Medical Humanities. The paper is a programmatic theory essay linking several rather distinct domains of inquiry. Therefore, much of the following will be rather broad-brushed. My hope is that decisiveness of positioning will outweigh potential losses in precision and detail.

\section{CRITICAL NEUROSCIENCE}

The brain has long become the 'signature organ' of the contemporary technologised, medicalised, digitalised landscape. To see why, note that the brain is doubly fascinating. First, the brain is the zone of intersection where matter meets mind: subjectivity, consciousness, agency-or whatever else supposedly constitutes the core of 'the human'-seems to finally yield to rigorous scientific investigation and technological intervention. As freshly emerging 'continental neurophilosophers' suggest, the assumption of a de facto equivalence of brain and mind survives even a thorough deconstruction of classical views of the mind, of consciousness, or personhood. ${ }^{6}{ }^{7}$ But second, the brain is at the same time credibly styled as one of the last true frontiers of science. In a world where every stone seems to have been turned, neuroscience has for some time excelled in presenting itself as one of the last hopes for profound novelty, for unprecedented empirical discovery and technological innovation. ${ }^{8}{ }^{9}$ For the past two decades, neuroscience has dwelled in the popular spotlight by selling itself as the hottest ticket aspiring to unveil the fundamental functioning principles of the central nervous system, thanks to its ever-more sophisticated measurement and intervention techniques. ${ }^{10}$ While the bonanza seems by and large over today (in 2015) —as technical limitations and methodological shortcomings are discussed on ever broader scales ${ }^{11}{ }^{12}$-the brain's iconic status as the locus of personhood and subjectivity, ${ }^{13}$ and as a prime site of biomedical intervention therein, remains largely unscathed. 
To put a label on the brain in this position of cultural salience, I will speak of 'the Neuro'. Rose and Abi-Rached use this term as the title of their wide-ranging assessment of the Neuro-Universe. ${ }^{14}$ The label is good for capturing the thought style and cluster of practices that have revolved around the brain in the past 50 or so years. The 'Neuro' focuses the brain in its co-articulation with scientific and medical practice, technologies, media representations and increasingly also policy. 'Neuro' denominates a broad field of knowledge-cum-practice, aspiring to the status of an epoch-defining episteme in Foucault's sense. That the 'Neuro'-signifier works well as an advertising label moreover highlights a central dimension of the contemporary situation. Twenty-first-century science is thoroughly commercialised and increasingly inextricable from practices of capitalist valuation, which means that public relations, consumer practices, aspects of a 'cultural industry' are added on to the practice of research to constitute 'venture science'.5 The cognitive, affective and social neurosciences have excelled in this terrain. ${ }^{15}$ That the focus of research has shifted from the hard-wired neural bases of individual capacities towards more socialinteractive and more plastic and situational characteristics resonates with broader zeitgeist trends-an indication of the 'Neuro's' versatility in adapting to a changing cultural ambient.

Critical Neuroscience is a multifaceted transdisciplinary approach to critically engage, situate and challenge this dynamic Neuro universe and its various adherents and followers inside and outside the neuroscientific laboratories. ${ }^{16}$ It is a broad scholarly perspective that aims at understanding the factors and trends that have come together to create and sustain the fascination with neuroscientific themes, it looks into the black boxes of neuroscientific tools and methods, and it strives to explore forms of subject formation through Neuro-related practices. ${ }^{10} 1718$ With these activities of exploration and assessment, critical neuroscience attempts to strike a fundamental balance. How does what has been newly learned about neuronal functioning in the course of the last decades' technical and methodological innovations measure up to what is potentially lost as a consequence of turning the brain into an 'obligatory point of passage' for knowledge of all things human? From a philosophical perspective, critical neuroscience aims to also identify fundamental intellectual and practical tendencies and virtualities that underlie the current overt face of the Neuro universe, such as a bio-perfection imperative, which consists of a reframing of both life and the mind as resource, potential and risk and the resolute drive towards technological perfection of the human condition, the push for neuro-enhancement in the register of what Sloterdijk has called 'anthropotechnics'19 (see also ref. 20).

Contrary to what some recent critical responses suggest, ${ }^{21} 22$ critical neuroscience is not a version of social constructivism. It neither presupposes nor aims to proclaim the ontological and/or epistemological priority of the socio-cultural over the neurophysiological. Instead, in line with much recent post-Science Wars Science and Technology Studies (STS) and philosophy of science, but against the sometimes de-politicising gist of some of that work, it assumes a levelled playing field between the fundamentally entangled practices of the natural sciences and the various social/cultural/humanist modes of inquiry. ${ }^{23} 24$ As Hans-Jörg Rheinberger has convincingly outlined, experimental science is as much a play of discursive traces, conceptual articulation, sign chains and ever-shifting practices of inscription, as well-made humanist scholarship is materially anchored, technically sophisticated and robustly embedded in fundamental reality. ${ }^{25}$ In light of this, the notorious 'two cultures-divide' must be seen as driven by political and institutional dynamics, and not as something that is ontologically 'deep'. ${ }^{17}$ While natural scientific practices differ in some notable respects from the practices in the Humanities, these differences do not pertain to the 'grip on' or 'anchoredness in' reality. It is the same reality that is materially discursively configured and re-configured both in the sciences and the humanities, in ways that either prove temporarily sustainable, able to productively align with other material-discursive practices, or else will sooner or later fall by the wayside. ${ }^{23}$ The lesson critical neuroscience draws from this constellation, and here it notably diverts from Latour'ian celebrations of hybridity, is the thorough re-politicising of scientific issues and stakes on all scales of science's operations and organisation. Thus, critical neuroscience emphatically re-invokes the 'the social'-albeit much less in ontological than in political terms. 'The social' is a perspective highlighting the-and intervening in-ongoing struggles for discursive, institutional and economic dominance that are fought out in and around the biomedical sciences. The present paper contributes to the appellative invocation of the inevitable political contestedness of basically all aspects of science-in-society.

\section{BIOCAPITAL AND VENTURE SCIENCE: TOWARDS A FRAMEWORK FOR CRITIQUE}

Kaushik Sunder Rajan has developed what might be taken as a template for the kind of actively politicising analysis that helps us get a firm grip on the role that 'the Neuro' has come to play today. While Sunder Rajan's subject matter is the global rise of the biotech industry in the wake of breakthroughs in genome research since circa 1980, a re-deployment of his analytical scheme in the domain of neuroscience is straightforward. Sunder Rajan's book Biocapital. The Constitution of Postgenomic Life ${ }^{5}$ revolves around two focal concepts, each denominating a fundamental driver of developments in science and society, and they both apply equally to genomics and to neuroscience: Life and Capital.

Life has long become the ultimate horizon of human valuation-and of the human imagination no less: we cannot truly think and feel beyond life, especially in modernity, where life has come to be the prime field of governance and regulation (Foucault's story). Capital is the one driving force of social organisation that achieved a truly global status as a structural determinant of virtually everything (Marx' story). Thus it is not surprising that the sparks fly when life and capital come together and, literally, procreate to bring forth biocapital. The focal terrain on which life and capital intermingle is technoscience - the commercialised and technologically enabled life sciences facilitate capital's invasion of life's ownmost dynamics. In this interventionist colonisation of vital processes, the everexpanding, perpetually growing commercialised health sector plays a crucial role. With life, capital and technoscience in place, two other nodes of the analytical network should be fairly easy to make out: politics, as the field of social action structured by relations of power in the broadest sense, and subjectivity, which takes on a quite specific formation in its constant co-mingling and modulatory interaction with the other nodes of the framework. Politics is never far where issues of life and capital are concerned, and today's predominant neoliberal politics entertains quite specific, epoch-defining relationships to life and capital. $^{26}$ Subjectivity enters the mix, on the one hand, in the form of subject formation and self-fashioning as enabled and propagated by current capital regimes, understandings and valuations of life and techno-medical environments; and, on the other hand, as the principle of ever-enhancing, ever-accelerating 
self-constitution of the shifting assemblage that is the contemporary subject.

As is good practice in the field of STS, Sunder Rajan operates with the assumption of a complex coproduction between various social, economic, scientific, technological, legal and regulatory developments. ${ }^{27}$ Instead of simplified linear models of causes or 'influences' and in place of conceptual purification procedures, we have to reckon with dense interrelations of processes and feedback loops on a number of scales. Accordingly, to gain traction on a field of societal practice, scholars have to operate at multiple registers simultaneously, without the hope of arriving at linear and self-evidently causal models, and without purified ontological separations. In his field of study, Sunder Rajan shows how legal and political reforms, scientific and technological innovations, business strategies, consumer practices, public discourses and long-standing cultural formations such as religion and nation have all played their role in a set of multiply intersecting trajectories that have reconfigured life and capital from about 1980 onwards. I will now summarise central nodes of this framework in order to illuminate the complex epistemic and ontological formation collected under the scope of 'biocapital'. I omit 'politics', but much of what is important under this rubric will surface along the way.

\section{Capital}

That "biotechnology represents a new face, and a new phase, of capitalism" (p. 277) ${ }^{5}$ is Sunder Rajan's central claim. Put technically, "the life sciences are overdetermined by capitalist political economic structures" (p. 6). ${ }^{5}$ Althusser's concept of overdetermination suggests a structural relationship between the capitalist economy and political, social and epistemic processes: the capitalist mode of social organisation is not the cause of, but

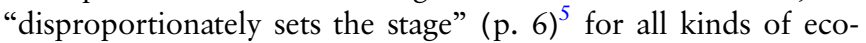
nomic formations as well as non-economic spheres of life. The capitalist economy is the one structuring factor that cannot be omitted in analysing social formations, importantly including contemporary science. Now, obviously, real-world capitalism is not a rigid, self-same structure, but an ensemble of constantly shifting and changing processes. Types of capital, modes of economic organisation, the logic of markets, practices of exchange and valuation: all change and mutate constantly-either in response to novel conditions or endogenously in order to optimise procedures or to expand towards new territories. Capitalism is unthinkable without constant evolution and mutation, creative destruction and rapid reorganisation and the emergences of new regimes. Epistemic and political formations evolve, shift and emerge accordingly.

A crucial transformation in capital that pertains to the development of the life sciences in the past 30 years has been the rise to dominance of speculative or 'venture' capital. Marx treated this 'merchant's capital' only marginally alongside industrial capital. $^{28}$ Today, venture capital has claimed centre stage. The global circulation of massive sums of investment money has brought with it changes in basic operating modes of companies and markets. Valuation has loosened its tie to direct commercial revenue and to economic fundamentals in general and instead became attached to estimated future profits in an increasingly forward-looking, speculative terrain. Supported by legal changes from the 1970s onwards, especially the USA has created an investment economy that displaces earlier forms of productionheavy industrial economy. At the same time, changes to intellectual property regimes and the facilitation of private/public partnerships enabled science to be brought into the ambit of

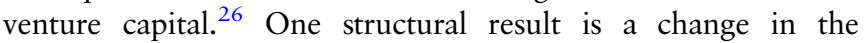

temporality of valuation: Present production capacities and present exchange value become less important, while a peculiar backward-causation of estimated future developments comes to be a decisive factor in shaping the economic and political situation. We see here a tangible 'materiality' of speculation. Visions of future developments, productivities and revenues enable concrete activities and materialisations in the present-speculative capital lets the future become manifest in the here and now:

...genomics, and indeed all biotechnology, is a game that is constantly played in the future in order to generate the present that enables the future. I therefore trace the conjuration of corporate promissory futures as a constitutive feature of biocapital... (p. $34 ;^{5}$ see also p. $24^{26}$ ).

The life sciences have thrived in this terrain, copiously promising novelty, hyping up the future in order to create stable expectations that are so central in the contemporary landscape of economic valuation. The unimaginable complexity, ontological centrality and riddlesome nature of the brain as a scientific object make for an especially ideal constellation: despite having rather little to offer in terms of already achieved or soon-to-be achieved marketable applications, neuroscience has thrived in selling gripping visions of possible futures, anchored in the brain's unique epistemic and imaginative status. ${ }^{15}$ Driven successfully by a scientifically enacted futurism, neuroscience is a poster child of venture capitalism.

\section{Life}

It might seem that, in every historical era, life itself poses a novel challenge to mankind's attempts at understanding it. Part of the task is to keep pace with rapid developments in science, industry, medical practice, legislation and policy, lifestyle and real-world ethics, while at the same time maintaining the conceptual resources that enable comprehension of the potential deep structures of vital processes. There is a hard-to-decipher dialectic of the old and the new, of change and stability in the domain of life. In the current epoch, life gets newly articulated, as it is increasingly amenable to technological manipulation, it is newly formatted as information (as in genomics), and-as a consequence of its novel accessibility, manipulability and decomposability-life is increasingly commoditised and mobilised as a resource and even as a 'currency' in global circulation (eg, blood, stem cells, various tissues, therapeutic molecules). Vital processes are reconceptualised on multiple scales-on the one hand, in informational terms (the genome) and component processes that might be disassembled and recombined at will, and, on the other hand, in terms of the statistical likelihood of certain disease events, so that life is understood as always potentially 'diseased life', it is at any time measurably 'at risk' and thus presumably in need of constant monitoring, early diagnosis and preventive maintenance. The numbers game of insurance practices takes hold of life, as regimes of planning, investment and 'providence management' are set up. "Life is a business plan" (p. 278) $)^{5}$-in the double sense of being in need of business-like planning by health-aware subjects, and by being the source of valuation of an ever-growing health economy. Assuming the futural logic of venture capitalism, life is framed in terms of credible futures that have to be invested in. As several authors have recently stressed, the two core meanings of the term 'value'-ethical and economic-intermingle productively: To the extent that 'life itself' is newly valorised in the ethos of late modern subjects ('somatic ethics', ${ }^{29}$ ) and recoded as constantly 'at risk', that is, shifting towards disease indication, life at all stages becomes subject to cost-intensive regimes of 
diagnosis, risk assessment, prevention, remediation, enhancement. Accordingly, 'Drugs for Life ${ }^{30}$ promise unlimited growth potential for the Pharma and Health industries. Life and capital, conceptual cousins from the outset, have met and fused again to create biocapital. ${ }^{26}$

\section{Technoscience}

The main arena in which the epoch-making marriage of life and capital is played out is 'technoscience'-a term that has been credibly invoked as an epoch-defining category, aspiring to supersede less informative labels such as 'late modernity'. 3132 Technoscience is a dispositif centred on science as a worldbuilding force. Science is here understood as enabled, constitutively formed and driven forward by technology, so that the procedures and operations of science have come to be inextricable from the employment of devices such as particle accelerators, brain scanners or recombinant DNA technologies. On the other hand, those constitutive technologies are not confined to the sites of scientific work, but reach out to structure reality as such. With regard to scientific world disclosure, today's signature technologies enable a more efficient, operational appropriation of nature-or, more radically, the transformation or recreation of nature, for example, through the production of a variety of 'technofacts'. ${ }^{31}$ In turn, technoscience comes with a transformed understanding of nature itself-in the world of technoscience, nature is no longer the diffuse organic 'other' set over against a circumscribed sphere of human practices, but rather a manipulable technosphere, inextricable from practices of appropriation, manipulation, purification-a realm of material potential for technological intervention, enhancement and creation. 'Nature' is brought into view as a hybrid sphere in which matter always already awaits its mobilisation, transformation and appropriation; multilayered techno-natural imbrications have become the ontological plane on which all relevant developments take place. Classical ontological divisions like those between nature and nurture, or between 'the natural' and 'the social' have fallen by the wayside.

Science in technoscientific times is at the same time 'Big Science', that is, science constitutively dependent upon massive, concentrated deployment of funds and an organisation in terms of grand-scale units (ie, industry-like set-ups in some disciplines at least; global networked structures in others, a good example is the recently established massive EU-funded Human Brain Project ${ }^{33}$ ). This also inevitably means that today's science takes the form of 'venture science,', that is, science not solely funded by the public sector but instead by private investors, capitalists and big industrial consortia. This profoundly changes the organisational structure of science, the role and self-understanding of individual scientists and especially the way science is oriented towards its own future, its internal logic of progress. ${ }^{34}$

Now, despite this radically transformed status quo of science in comparison with its former manifestations, contemporary self-proclamations of technoscientists are still often steeped in 'representation talk', reifying and objectifying nature and claims of epistemic authority and 'realism' reign supreme. Neuroscience, no less, has drawn some of its cultural capital from its adherence to an eminently 'realist' epistemic priority over other forms of discourse on human affairs. Even if this has begun to change in face of recent methodological impasses in the field, one might still diagnose a marked discrepancy between the de facto procedures, the acted-out epistemologies and ontologies of technoscience and the somewhat outdated scientific self-understanding of their practitioners. However, it is this very understanding-in its relying on the classical authority of science in speaking truth and saying nature-that is itself instrumental in the establishment of technoscience. Science's assumed epistemic authority helps anchor technoscience firmly within the contemporary cultural landscape.

The mythological self-styling of contemporary science with its futuristic promises and visions (including its apocalyptic flip side so often drawn upon in dystopic literary and cinematic works) helps create a cultural 'techno imaginary'-dissolving the borders between science and fiction, suggesting fantasies of unlimited welfare and technological omnipotence ('singularity', artificial life, see, eg, ${ }^{35}$ ), which in turn contributes to the essential hype-creation so integral to venture science. So even its alleged 'cultural other' fulfils a functional role in technoscience's emergence as an epoch-defining formation.

\section{Subjectivity}

Subjectivity is of massive importance to any endeavour aspiring to 'critique' in a substantive sense of the word. Subjectivity, whatever its formative history and constitutional trajectory, is the site where coercive processes and social pathologies will exert their effects most strikingly. Subjectivity is the terrain where processes of suppression, various machinic mouldings and the production of suffering play their various games. Subjectivity, when crystallised into the stable position of 'the subject', embodies-and thus can painfully fail to realisehuman potentialities. Instead, subjectivity may take on variously deformed or even monstrous guises as a result of the coercive workings of power. But at the same time, and in virtue of these very potentialities, subjectivity is inevitably implicated in whatever positive, hopeful route or trajectory is chosen in attempts to move beyond the status quo. The subject, however contingent its formation and however shifting in its shapes and its substance, is the instance to be empowered, restored to something near enough to autonomous agency, endowed with the means of emancipation. Whatever concrete form emancipation is proposed to take, it will inevitably work towards differently configured, differently oriented subject positions. Thus, it is time to discuss the subject positions and formations of subjectivity implicated in the global rise of biocapital.

The short version of Sunder Rajan's entanglement narrative goes as follows. Venture capital, the new understanding of life as risk and contemporary technoscience are woven together in the emergence of a novel cluster of characteristic subject positions. Most notable among these is the 'prospective health consumer'. In part, it is the economic pressure towards solid returns on investments made in biomedical research that helps mobilise the novel configuration of life as 'at risk of disease'. This configuration will then drive the interpellation a new kind of subject: the 'patient-in-waiting' that will at the same time be a 'consumer-in-waiting', once the right kinds of diagnostic and preventive products are made available on the health market (pp. 167-77). ${ }^{5}$ Besides producing the knowledge and applications enabling this reconfiguration of the subject in practice, the biomedical sciences also crucially function as a source of discursive authority, establishing conceptual frameworks that, once the label 'scientific' attaches to them, exert robust effects on processes of subjective self-fashioning. The technoscience of genomics, driven forward by venture capital's commodification imperative, thus functions simultaneously in materialproductive, epistemic and rhetorical ways so as to help configure a novel formation of consumer subjectivity. At this point, Sunder Rajan's account runs in parallel to that of fellow medical anthropologist Joseph Dumit, who introduced the concept of "objective self-fashioning" in order to describe the mode of 
subjectification that is in play here. ${ }^{36}$ Dumit uses the notion of 'objective self-fashioning' to designate the complex process in which expert knowledge and individual self-styling come together to create a formation of subjectivity and enacted way of life in terms of currently available scientific facts. ${ }^{36}$

The background enabling condition for the emergence of the 'patient-in-waiting' is the current shape of the deregulated neoliberal global economy. As Sunder Rajan argues, the category of 'risk' plays a central role here. 'Risk' enters the scene from two sides at once. On the one hand, investors take financial risks by funding research in nascent biotechnologies whose commoditisation potential is highly uncertain. On the other hand, particularly genome-based biotechnologies-but also some of the technologies employed in neuroscience-construe their subject matter in probabilistic terms, namely according to the statistical likelihood of certain disease events. Capital is at risk when invested in prospective technologies that construe life itself as risk. What helps both investors and consumers in managing their respective risks is preventive medicine. Moving from therapy of manifest illness towards precaution, prevention, risk assessment and diagnosis, the new techno-medical regime addresses clients that worry about being at risk of developing diseases in the future, thereby enlarging the number of prospective consumers of health products to ultimately encompass "everyone with purchasing power" (p. 175). ${ }^{5}$ A newly configured understanding of health and illness opens up new markets as it sets the stage for a novel health-aware, risk-assessing, prevention-oriented subject. Why wait to be manifestly ill when the hazards are already at work, hidden from view, in the very organic processes that constitute your own life? Take action now! Dumit's Drugs for Life ${ }^{30}$ explores the coming into being of this new medico-ethical orientation in great detail.

There is an important philosophical dimension to this. Capitalism in general is the mobilising of vital processes in order to generate surplus value. Human life in itself is more and more on the way to become the ultimate horizon of valuation in a secular, individualistic, post-heroic age. ${ }^{29}$ To late modern subjects, little is quite as desirable as their own life as it constitutes an absolute sphere of intrinsic value ('quality of life'). At the same time, this very life is perpetually expiring, inevitably dwindling towards its organic doomsday. From the perspective of capitalism, life's absolute intrinsic value combined with its essential mortality presents an inexhaustible formula for surplus value generation. According to this logic, the fight against fleshly peril-although inevitably lost in each case in the long run-must be fought perpetually. With every specific 'death' that has been provisionally prevented with the help of medical products and procedures, an indefinite number of other possible 'deaths' may come in view. As long as life itself remains the ultimate value orienting individual existence, an infinity of lifeenhancing, illness-preventing measures will be desired and demanded.

Looked at from a pessimistic angle, what seems to have appeared on the scene is the sad figure of a self-possessed consumer, absorbed entirely within its homely sphere of somatic well-being, wrapped securely in a techno habitat, constantly anxious about the inevitable prospect of fleshly peril. We are left with a fearful, risk-obsessed health consumer whose ethical horizon rarely exceeds the bounds of the individual's somatic existence. ${ }^{29}$ Agency gets more and more narrowed down to consumer choices and to 'pro-active' behaviours in line with the recommendations of expert bodies. While the 'activist subject' of the enlightenment turned everything into a resource, its contemporary counterparts are becoming resources themselves- resoundingly demobilised except as clients/users, certainly with regard to the blessings of an expanding health economy that has managed to create a profound dependence in core dimensions of human existence.

\section{CRITICAL NEUROSCIENCE MEETS MEDICAL HUMANITIES}

What does the Neuro domain specifically contribute to contemporary bio-techno-medical interpellation? Against the partially shared background of the capital-driven, scientifically reframed perspective on human life as resource and risk, we see in this domain the emergence of a somewhat differently configured subject position and of differently configured visions of a technoscientific future. The brain functions as a marker of personal identity and as the privileged terrain for processes of selfimprovement and optimisation, and thereby as the anchoring point of novel responsibilities. The post-fordist watchword "mental capital' 37 captures this role of the brain as a locus of vital potential that demands cultivation from very early until very late in a human life, expressing a focus on cognitive and emotional profiles and skillsets. ${ }^{38}$ The concept operates in concert with an emerging form of natural normativity, insofar as the brain's constitution as disclosed by neuroscience is increasingly invoked to place concrete self-cultivation demands on individuals. ${ }^{39}$

In contrast to the biomedical domain at large, and despite the constant talk about tangible benefits, novel tools or medically relevant insights, human neuroscience has so far operated in a more specifically discursive register. It has offered interpretations, templates for self-understanding and promissory outlooks into a future of technological self-optimisation, rather than a whole lot of marketable applications. ${ }^{10}$ One might even speak of a crisis of neuro-commodification, for example, in the field of neuropharmacology, where initial enthusiasm (eg, in the wake of the introduction of PROZAC 25 years ago) has turned into mostly disappointment due to very little measurable progress despite massive investments. ${ }^{14}$ In light of this, one might view the current discursive framing of the brain as 'the Neuro' to function as a placeholder for an anticipated future, the dawn of Humanity 2.0.20 The Neuro anchors anticipation, in a materially salient and rhetorically impactful way, of the future of humanity, as a variously optimised, cognitively enhanced, endurable and resilient form of life. ${ }^{10}$ In fact, the human neurosciences crystallise the futuristic trajectory of contemporary life sciences in a much more purified way than most other fields. One example is the scientific programme of the EU-funded Human Brain Project that includes much that is utter science fiction. ${ }^{33}$ That this massive project got away with this despite a widespread sense, in expert circles at least, that its research goals are highly unrealistic indicates that neuroscience operates in a different discursive terrain than many other natural sciences. $^{4041}$ Technoscientific futurality is part of its operative logic. The conceptually confusing character of the mind/brain relationship facilitates this development. To an equal measure, this trend is driven by the cultural salience of all things cerebral in today's digitalised environments, besides being also propelled by the general futurality of 21 st-century technoscience. There is no other scientific domain where 'promise' could be housed in a comparably murky conceptual impasse that is at the same time so close to the very core of human self-understanding. While the health industry has learned to turn human mortality into an inexhaustible profit formula, neuroscience has settled in a lacuna of human self-understanding, in the riddlesome material pinnacle of who we are. 
The futuristic vision has an operative flip side: neuronormativity. The brain's presumed functioning is increasingly invoked to place normative demands upon individuals. ${ }^{39}$ Neuroscientists assume the role of experts that speak authoritatively about how we should live, learn, love, work and care for ourselves and for others-since this is what proper brain development, maintenance and regeneration presumably demand. This emerging neuro-normativity is a part of the larger discursive and practical tendencies described above. The cerebral aligns with the 'life and health' configuration by adding several further dimensions to it. For example, the brain is invoked to promote a conception of a naturalised sociality, crystallised in the image of the empathic personality. Relatedly, the cerebral aligns well with the skill profile of the ideal employer in a flexible, constantly changing knowledge economy and its everevolving informational environments. The 'prospective health consumer' is thus joined by the flexible and creative 'team player' of the post-fordist work world, ${ }^{38}$ who usually also happens to coincide with the constantly up-to-date 'user'-the model subject of the blossoming worlds of information and communication technology. ${ }^{42}$

What might the critical Medical Humanities learn from both the Biocaptial framework and its transformative application within critical neuroscience? Besides the direct continuation of Sunder Rajan's analysis of the Biotech sector and related fields of practice-whose object of study qualifies it for immediate enrolment within the Medical Humanities canon-I see predominantly two general tasks and trajectories for critique. First, focus has to be on the organising and transformative potential of salient concepts. For example, emphasis might be placed on concepts such as life, risk, health, well-being, mental capital, empathy, resilience that are implicated in ongoing transformations of crucial sectors of reality, changing their meaning in line with complex processes of co-production in sectors such as medicine, science, marketing, management, finance, education and surely media. Concepts in general-including the respective domains or milieux in which they are situated-can be considered a 'method' of critical cultural studies, as concepts travel both diachronically through different epochs and synchronically through various domains of applications, thereby transforming local understandings but also transforming themselves, picking up novel connotations and exerting various, often subtle impacts in many directions. ${ }^{43}$ As I hope to have illustrated with regard to several salient concepts above, this charting of transformative trajectories and reflection upon their various ramifications can be a valuable strategy in any robustly critical endeavour. Of course, there are variable degrees of 'criticalness' to those studies of conceptual trajectories. Perhaps not surprisingly, I opt for an overall more rigorous positioning on part of critical scholars, I would like to see more of a readiness to blame and dismiss besides all the careful chartings, probings and mappings that have become the standard in much of cultural studies today. So for instance, to name just one example, we need more work like the refreshingly rigorous dismissal of the concept of 'resilience' by Evans and Reid. ${ }^{44}$ Further hints as to which concepts might be worthwhile objects of study for the critical Medical Humanities are provided by Atkinson et $a l^{45}-$ for instance, they suggest the development of relational conceptions of subjectivity to counter neoliberal individualism, and they point to work on the specific value of negative emotionality to counter the widespread one-sided narratives of "positivity and praise for heroic survivorship" (p. 77). ${ }^{45}$

Second, in a more consciously self-reflective turn, the Humanities' own implications in the processes and realities under study should be part of the analysis. This brings me back to the beginning of this article, to Cooter's and Stein's apt warnings as to the role and position of today's Humanist scholars vis-à-vis the emerging biomedical sciences. What is needed is more of a critical consciousness of the strategic positioning and potentially ideological use of humanist scholarship. "[T]hrough the very act of observing this professed new 'biological age,' its ethnographers also market it. In their determinist claims for the new bio-knowledges and practices, they unwittingly perform for the professional, commercial, and political interests invested in the claims" (p. 3). ${ }^{1}$ What this entails for a robustly critical inquiry is a more self-consciously strategic employment of the terms, positions and directions of analysis-an analytically shaped awareness of both one's own standpoint and formative trajectory as a critic, and the position and potential impact of the very forms of scholarship that one conducts, the associations one forms or is invited to join, the themes one deems worthy of study and so on. Work in the Humanities is always a strategic move in a complexly configured field of power relations. We should not allow ourselves to be blinded to this fact. It is time to avow a critical responsibility in the essentially contested terrains that shape human lives in the present, and use one's own academic field, one's analytical tools and one's alliances strategically in order to intervene in the very realities under study. In practice, this might of course mean very different things to different scholars in the Medical Humanities. To name just one perspective, it could-perhaps should-entail rigorous opposition to the altogether undisruptive conception of the Medical Humanities as medicine's 'supportive friend', ${ }^{46}$ and likewise to the shallow propagation of often highly gendered conceptions of empathy and emotionality in the medical encounter.

Overall, I think that the Medical Humanities are in an excellent position to become not only a valuable avenue to enriched understandings of developments in and around today's biomedical sciences and their multiple ramifications, but also an exemplary site for self-consciously engaged critical scholarship and informed ways of political contestation that can live up to the challenges of the present.

Acknowledgements I would like to thank Angela Woods, Felicity Callard and Will Viney for their patience and their many helpful comments to earlier versions. I also thank two anonymous reviewers for a number of excellent suggestions to improve the paper.

Competing interests None declared.

Provenance and peer review Not commissioned; externally peer reviewed.

\section{REFERENCES}

1 Cooter R, Stein C. Writing history in the age of biomedicine. New Haven and London: Yale University Press, 2013.

2 Whitehead A., Woods A. The Edinburgh companion to the critical medical humanities. Edinburgh: Edinburgh University Press, forthcoming.

3 Latour B. Why critique has run out of steam: from matters of fact to matters of concern. Critical Inquiry 2004;30:225-48.

4 Braidotti R. The posthuman. Cambridge: Polity Press, 2013.

5 Sunder Rajan K. Biocapital: The constitution of postgenomic life. Durham, N.C: Duke University Press, 2006.

6 Johnston A, Malabou C. Self and emotional life: philosophy, psychoanalysis, and neuroscience. New York: Columbia University Press, 2013.

7 Malabou C. The new wounded: from neurosis to brain damage. New York: Fordham University Press, 2012.

8 Zeki Z. Splendors and miseries of the brain: love, creativity, and the quest for human happiness. Oxford: Wiley, 2008.

9 Elger CE, Friederici AD, Koch C, et al. Das Manifest: Elf führende Neurowissenschaftler über Gegenwart und Zukunft der Hirnforschung. Gehirn und Geist 2004;6:30-7.

10 Slaby J, Gallagher S. Critical neuroscience and socially extended minds. Theory Cult Soc 2015:32(1):33-59.

11 Satel S, Lilienfield SO. Brainwashed: the seductive appeal of mindless neuroscience. New York: Basic Books, 2013. 
12 Stelzer J, Lohmann G, Mueller K, et al. Deficient approaches to human neuroimaging. Front Hum Neurosci 2014;8:462.

13 Vidal F. Brainhood: anthropological figure of modernity. Hist Human Sci 2009;22 (1):6-36.

14 Rose N, Abi-Rached JM. Neuro: the new brain sciences and the management of mind. Princeton: Princeton University Press, 2013.

15 Lynch Z. The neuro revolution: how brain science is changing our world. New York: St. Martin's Griffin, 2009.

16 Choudhury S, Slaby J, eds. Critical neuroscience: a handbook of the social and cultural contexts of neuroscience. Chichester/West Sussex: Wiley-Blackwell, 2012.

17 Slaby J, Haueis P, Choudhury S. Neuroscience as applied hermeneutics: toward a critical neuroscience of Political Theory. In: Vander Falk F, ed. Essays on neuroscience and political theory. New York: Routledge, 2012:50-73.

18 Choudhury S, McKinney KA. Digital media, the developing brain and the interpretive plasticity of neuroplasticity. Transcult Psychiatry 2013;50:192-215.

19 Sloterdijk P. You must change your life (W. Hoban trans.). Cambridge: Polity Press, 2012.

20 Fuller S. Humanity 2.0. What it means to be human, past present and future. London: Palgrave MacMillan, 2011.

21 Fitzgerald D, Matusall S, Skewes J, et al. What's so critical about critical neuroscience? Rethinking experiment, enacting critique. Front Hum Neurosci 2014;8:365.

22 Fitzgerald D, Callard F. Social science and neuroscience beyond interdisciplinarity: experimental entanglements. Theory Cult Soc 2015;32(1):3-32.

23 Rouse J. How scientific practices matter: reclaiming philosophical naturalism. Chicago: University of Chicago Press, 2002.

24 Barad K. Meeting the universe halfway: quantum physics and the entanglement of matter and meaning. Durham, NC: Duke University Press, 2007.

25 Rheinberger H.-J. Toward a history of epistemic things. Stanford: Stanford University Press, 1997.

26 Cooper M. Life as surplus: biotechnology and capitalism in the neoliberal era. Seattle, WA: University of Washington Press, 2008.

27 Jasanoff S, ed. States of Knowledge: the co-production of science and social order. London: Routledge, 2004.

28 Marx K. Capital: a critique of political economy. Vol 3. Engels F, ed. Moscow: Progress Publishers, 1974.

29 Rose N. The politics of life itself: biomedicine, politics, and subjectivity in the $21^{\text {st }}$ century. Princeton: Princeton University Press, 2007.
30 Dumit J. Drugs for life: how pharmaceutical companies define our health. Durham, NC: Duke University Press, 2012.

31 Weber J. Umkämpfte Bedeutungen. Naturkonzepte im Zeitalter der Technoscience. Frankfurt/M: Campus, 2003.

32 Haraway D. Modest_Witness@Second_Millenium.FemaleMan@_Meets_ OncoMouse $\mathrm{TM}$ : Feminism and technoscience. London/New York: Routledge, 1997.

33 The Human Brain Project-Framework Partnership Agreement (HBP-FPA). https:// www.humanbrainproject.eu/documents/10180/538356/HBP_FPA_PRINT_29-07-14. pdf (accessed 19 Mar 2015)

34 Mirowski P. Science-mart: privatizing American science. Cambridge, MA: Harvard University Press, 2011.

35 Kurzweil R. The singularity is near: when humans transcend biology. London: Viking, 2005.

36 Dumit J. Picturing personhood. Brain scans and biomedical identity. Princeton: Princeton University Press, 2004.

37 Beddington J, Cooper CL, Field, J, et al. The mental wealth of nations. Nature 2008;455:1057-60.

38 Malabou C. What should we do with our brain? New York: Fordham University Press, 2008.

39 Hartmann M. Against first nature: critical theory and neuroscience. In: Choudhury S, Slaby J, eds. Critical neuroscience: a handbook of the social and cultural contexts of neuroscience. Chichester/West Sussex: Wiley-Blackwell, 2012:67-84.

40 Fregnac Y. Laurent G. Neuroscience: Where is the brain in the Human Brain Project? Nature 2014;517:27-9.

41 Haueis $\mathrm{P}$, Slaby J. Brain in a shell: an assessment and critique of the transformative potential of the Human Brain Project. In: De Vos J, Pluth E, eds. Neuroscience and critique. New York: Routledge, forthcoming.

42 Stadler M. Neurohistory is bunk? The not-so-deep history of the post-classical mind. Isis 2014;105(1):133-44.

43 Bal M. Traveling concepts in the humanities: a rough guide. Toronto: University of Toronto Press, 2002.

44 Evans B, Reid J. Resilient life: the art of living dangerously. London: Polity, 2014.

45 Atkinson S, Evans B, Woods A, et al. 'The medical' and 'health' in a critical medical humanities J Med Humanit 2015;36(1):71-81.

46 Brody $H$. Defining the medical humanities: three conceptions and three narratives. J Med Humanit 2011;32:1-7. 